\title{
Construction of a pH-Driven Supramolecular Nanovalve
}

Thoi D. Nguyen, Ken C.-F. Leung, Monty Liong, Cari Pentecost,

J. Fraser Stoddart, ${ }^{*}$ and Jeffrey I. Zink *

California NanoSystems Institute and Department of Chemistry and Biochemistry,

University of California, Los Angeles, 405 Hilgard Avenue, Los Angeles,

CA 90095, USA

\section{Supporting Information}

\begin{tabular}{|l|}
\hline \multicolumn{1}{|c|}{ Correspondence Addresses } \\
\hline Professor J Fraser Stoddart \\
California NanoSystems Institute and \\
Department of Chemistry and Biochemistry \\
University of California, Los Angeles \\
405 Hilgard Avenue \\
Los Angeles, CA 90095-1569 (USA) \\
Tel: (+1)-310-206-7078 \\
Fax: (+1)-310-206-1843 \\
Email: stoddart@,chem.ucla.edu \\
Professor Jeffrey I. Zink \\
California NanoSystems Institute and \\
Department of Chemistry and Biochemistry \\
University of California, Los Angeles \\
405 Hilgard Avenue \\
Los Angeles, CA 90095-1569 (USA) \\
Tel: (+1)-310-825-1001 \\
Fax: (+1)-310-206-4038 \\
Email: zink@.chem.ucla.edu \\
\end{tabular}


Synthesis. To begin with, the methyl ester 1 was reduced (Scheme S1) by $\mathrm{LiAlH}_{4}$ in tetrahydrofuran (THF) to afford the alcohol 2 in 97\% yield. Subsequently, the alcohol 2 was oxidized into the corresponding aldehyde $\mathbf{3}$ using pyridinium chlorochromate (PCC) as the oxidant in $98 \%$ yield. Then, by refluxing a mixture of the aldehyde 3 and 4 fluorobenzylamine (4) in PhMe in a Dean-Stark apparatus to remove the $\mathrm{H}_{2} \mathrm{O}$ formed from the reaction, which in turn, treating with $\mathrm{NaBH}_{4}$, gave the corresponding amine $\mathbf{5}$ in 91\% yield. Furthermore, the free amine $\mathbf{5}$ was protected with a tert-butyloxycarbonyl (Boc) group by reacting with di-tert-butyl dicarbonate $\left(\mathrm{Boc}_{2} \mathrm{O}\right)$, resulting in the formation of the $N$-Boc-protected amine $\mathbf{6}$ in $98 \%$ yield. Finally, the benzyl group of the compound 6 was removed under a hydrogenolysis condition to give the naphthol 7 in $71 \%$ yield.

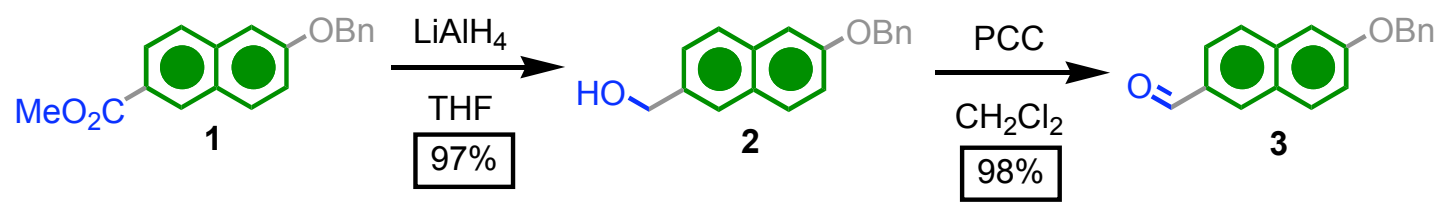

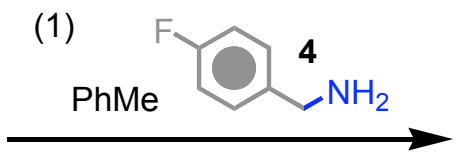

(2) $\mathrm{NaBH}_{4} / \mathrm{MeOH} / \mathrm{THF}$ $91 \%$

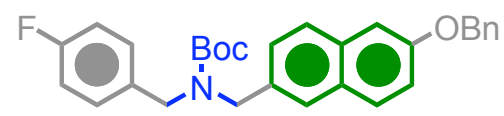

6
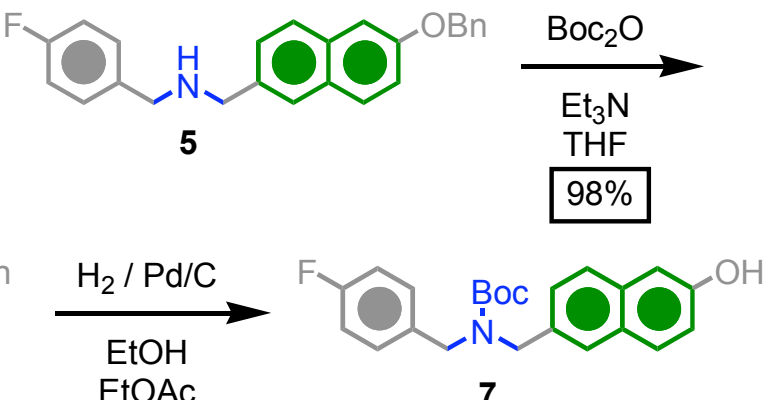

$71 \%$

Scheme S1. Synthesis of naphthalene-containing precursor compound 7.

Materials and Methods. 4-Fluorobenzylamine (4) is commercially available while compound $\mathbf{1}^{1}$ was synthesized according to the literature procedures. All reagents were 
purchased from commercial suppliers (Aldrich) and used without purification. Thin layer chromatography (TLC) was performed on silica gel $60 \mathrm{~F}_{254}$ (E. Merck). Column chromatography was performed on silica gel 60F (Merck 9385, 0.040-0.063 mm). All nuclear magnetic resonance (NMR) spectra were recorded on a Bruker Avance $500\left({ }^{1} \mathrm{H}\right.$ : $500 \mathrm{MHz} ;{ }^{13} \mathrm{C}: 126 \mathrm{MHz}$ ) spectrometer and $\mathrm{CDCl}_{3}$ was used as the solvent. Chemical shifts are reported as parts per million (ppm) downfield from the $\mathrm{Me}_{4} \mathrm{Si}$ resonance as the internal standard for both ${ }^{1} \mathrm{H}$ and ${ }^{13} \mathrm{C}$ NMR spectroscopies. Electrospray ionization (ESI) mass spectra were measured on a VG ProSpec triple focusing mass spectrometer with $\mathrm{MeCN}$ as the mobile phase. High-resolution matrix-assisted laser desorption ionization (HR-MALDI) spectra were measured on an IonSpec Fourier transform mass spectrometer. The reported molecular mass $(\mathrm{m} / \mathrm{z})$ values correspond to the most abundant monoisotopic masses. X-Ray diffraction (XRD) analysis was performed using Philips X'Pert Pro. Scanning electron microscopic (SEM) image was collected using a JEOL SM-71010 apparatus. Gold coating of the material for SEM imaging was performed with a Gold Sputterer (Hummer ${ }^{\circledR}$ 6.2, Anatech LTD, plasma discharge current $=15 \mathrm{~mA}$ at 70 mTorr, 2 min). Nitrogen isotherms were measured using Micromeritics ASAP 2000. The controlled release of coumarin 460 into solution was monitored over time using luminescence spectroscopy (Acton SpectraPro 2300i CCD).

Alcohol 2. A mixture of the ester $\mathbf{1}^{1}(1.6 \mathrm{~g}, 5.5 \mathrm{mmol})$ in THF $(10 \mathrm{~mL})$ was added dropwise to a slurry of $\mathrm{LiAlH}_{4}(0.42 \mathrm{~g}, 11 \mathrm{mmol})$ in THF $(10 \mathrm{~mL})$ at $0{ }^{\circ} \mathrm{C}$. The reaction mixture was allowed to stir for $3 \mathrm{~h}$ at $25{ }^{\circ} \mathrm{C}$ under $\mathrm{Ar}(1 \mathrm{~atm})$. Subsequently, the mixture was quenched carefully by the dropwise addition of $\mathrm{H}_{2} \mathrm{O}(1 \mathrm{~mL})$ and then $1 \mathrm{M} \mathrm{HCl}(30$ 
$\mathrm{mL})$, followed by two consecutive extractions with EtOAc $(20 \mathrm{~mL})$. The combined organic extracts were dried $\left(\mathrm{MgSO}_{4}\right)$ and filtered. The filtrate was concentrated under reduced pressure and the residue was purified by column chromatography using hexane/EtOAc (2:1) as the eluent to give the alcohol 2 (1.4 g, 97\% yield) as a white solid. M.p.: $120.6-123.8^{\circ} \mathrm{C} ;{ }^{1} \mathrm{H}$ NMR: $1.70(\mathrm{t}, J=5.6 \mathrm{~Hz}, 1 \mathrm{H}), 4.83(\mathrm{~d}, J=5.1 \mathrm{~Hz}, 2 \mathrm{H}), 5.19$ (s, 2 H), 7.21-7.25 (m, 2 H), 7.32-7.50 (m, 6 H), 7.70-7.76 (m, 3 H); ${ }^{13} \mathrm{C}$ NMR: 65.5, $69.9,106.9,119.2,125.5,127.1,127.2,128.0,128.4,128.6,129.3,129.4,133.9,136.0$, 136.7, 156.8; MS(HR-ESI): calcd for $\mathrm{C}_{18} \mathrm{H}_{16} \mathrm{O}_{2} \mathrm{~m} / z=264.1150$; found $m / z=264.1138$ $\left[\mathrm{M}^{+}, 100 \%\right]$.

Aldehyde 3. A mixture of the alcohol $2(0.20 \mathrm{~g}, 0.76 \mathrm{mmol})$ and pyridinium chlorochromate (PCC) $(0.33 \mathrm{~g}, 1.5 \mathrm{mmol})$ in $\mathrm{CH}_{2} \mathrm{Cl}_{2}(5 \mathrm{~mL})$ was stirred at $25{ }^{\circ} \mathrm{C}$ under $\operatorname{Ar}(1 \mathrm{~atm})$ for $2 \mathrm{~h}$ prior to filtration through a short pad of silica gel. The filtrate was then concentrated under reduced pressure. The residue was purified by column chromatography using hexane/EtOAc (5:1) as the eluent to afford the aldehyde $3(0.19 \mathrm{~g}$, 98\% yield) as a white solid. M.p.: $126.4-129.2{ }^{\circ} \mathrm{C} ;{ }^{1} \mathrm{H}$ NMR: 5.17 (s, $2 \mathrm{H}$ ), 7.00 (d, $J=$ $9.2 \mathrm{~Hz}, 1 \mathrm{H}), 7.28-7.38$ (m, $6 \mathrm{H}), 7.55(\mathrm{~d}, J=8.4 \mathrm{~Hz}, 1 \mathrm{H}), 7.69-7.76$ (m, $2 \mathrm{H}), 7.92$ (d, $J=9.2 \mathrm{~Hz}, 1 \mathrm{H}), 9.98(\mathrm{~s}, 1 \mathrm{H}) ;{ }^{13} \mathrm{C}$ NMR: 70.0, 107.0, 119.5, 125.6, 127.2, 127.3, 128.1, 128.4, 128.7, 129.4, 134.0, 136.3, 140.0, 160.0, 190.1; MS(HR-ESI): calcd for $\mathrm{C}_{18} \mathrm{H}_{14} \mathrm{O}_{2}$ $m / z=262.0994 ;$ found $m / z=262.1003\left[\mathrm{M}^{+}, 100 \%\right]$.

Amine 5. A mixture of the 4-fluorobenzylamine $4(0.70 \mathrm{~mL}, 5.3 \mathrm{mmol})$ and the aldehyde $3(1.4 \mathrm{~g}, 5.3 \mathrm{mmol})$ in PhMe $(20 \mathrm{~mL})$ was stirred and heated under reflux in a Dean-Stark 
apparatus for $12 \mathrm{~h}$. Subsequently, the mixture was cooled down to room temperature and excess of solvent was evaporated off under reduced pressure to afford an oil. Next, the resulting oil was redissolved in a THF/MeOH $(2: 1,30 \mathrm{~mL})$ mixture and $\mathrm{NaBH}_{4}(0.61 \mathrm{~g}$, 16 mmol) was added portionwise at $0{ }^{\circ} \mathrm{C}$. The reaction mixture was then stirred at $25{ }^{\circ} \mathrm{C}$ for $12 \mathrm{~h} . \mathrm{H}_{2} \mathrm{O}(30 \mathrm{~mL})$ was added dropwise to quench the reaction and the resulting mixture was extracted with EtOAc $(20 \mathrm{~mL})$ twice. The combined organic extracts were dried $\left(\mathrm{MgSO}_{4}\right)$ and filtered. The filtrate was concentrated under reduced pressure and the residue was purified by column chromatography using hexane/EtOAc (3:1) as the eluent to give the amine 4 (1.8 g, 91\% yield) as a white solid. M.p.: $67.6-69.8{ }^{\circ} \mathrm{C} ;{ }^{1} \mathrm{H}$ NMR: 1.74 (brs, $1 \mathrm{H}), 3.81$ (s, $2 \mathrm{H}), 3.93$ (s, $2 \mathrm{H}), 5.18$ (s, $2 \mathrm{H}), 7.00-7.05$ (m, $3 \mathrm{H}), 7.28-7.45$ (m, $7 \mathrm{H}), 7.50(\mathrm{~d}, J=7.4 \mathrm{~Hz}, 2 \mathrm{H}), 7.67-7.75(\mathrm{~m}, 3 \mathrm{H}) ;{ }^{13} \mathrm{C}$ NMR: 49.1, 52.2, 69.9, 107.1, 114.9, 115.1, 119.1, 119.2, 126.3, 127.0, 128.4, 128.9, 129.0, 129.1, 129.2, 129.5, 133.6, 135.2, 136.8, 156.6, 162.9; MS(HR-ESI): calcd for $\mathrm{C}_{25} \mathrm{H}_{22} \mathrm{FNO} m / z=371.1685$; found $m / z=371.1690\left[\mathrm{M}^{+}, 100 \%\right]$

$N$-Boc-Protected Amine 6. $\mathrm{Boc}_{2} \mathrm{O}(1.3 \mathrm{~g}, 5.8 \mathrm{mmol})$ in THF $(10 \mathrm{~mL})$ was added dropwise to a mixture of the amine $5(1.8 \mathrm{~g}, 4.9 \mathrm{mmol}), \mathrm{Et}_{3} \mathrm{~N}(1.4 \mathrm{~mL}, 9.7 \mathrm{mmol})$ and catalytic amount of $N, N^{\prime}$-dimethylaminopyridine in THF $(15 \mathrm{~mL})$ at $0{ }^{\circ} \mathrm{C}$ under $\operatorname{Ar}(1$ atm). The reaction mixture was stirred for $12 \mathrm{~h}$ before it was quenched by the addition of $\mathrm{H}_{2} \mathrm{O}(20 \mathrm{~mL})$. Subsequently, the resulting mixture was extracted with EtOAc $(20 \mathrm{~mL})$ twice. The combined organic extracts were dried $\left(\mathrm{MgSO}_{4}\right)$, filtered and the filtrate concentrated under reduced pressure to give a residue, which was purified by column chromatography using hexane/EtOAc (6:1) as the eluent to afford the $N$-Boc-protected 
amine 6 (2.3 g, 98\% yield) as a white solid. M.p.: $79.4-81.6{ }^{\circ} \mathrm{C} ;{ }^{1} \mathrm{H}$ NMR: $1.56(\mathrm{~s}, 9 \mathrm{H})$, 4.22-4.50 (br, 4 H), 5.19 (s, 2 H), 7.01 (dd, $J=8.6$ Hz, 4 H), 7.15-7.25 (br, 3 H), 7.36 (d, $J=7.2 \mathrm{~Hz}, 2 \mathrm{H}), 7.41(\mathrm{dd}, J=7.5 \mathrm{~Hz}, 2 \mathrm{H}), 7.50$ (d, $J=7.8 \mathrm{~Hz}, 2 \mathrm{H}), 7.68-7.75$ (m, 2 $\mathrm{H}) ;{ }^{13} \mathrm{C}$ NMR: 28.6, 48.4, 49.3, 60.3, 76.7, 107.0, 115.2, 119.2, 126.6, 127.2, 127.5, $127.9,128.5,128.8,128.9,129.1,129.5,132.9,133.7,136.7,156.7,161.0,162.9$; MS(HR-ESI): calcd for $\mathrm{C}_{30} \mathrm{H}_{30} \mathrm{FNNa} m / z=494.2102$; found $m / z=494.2104\left[(\mathrm{M}+\mathrm{Na})^{+}\right.$, $100 \%]$

Naphthol 7. A mixture of the $N$-Boc-protected amine $6(1.4 \mathrm{~g}, 3.0 \mathrm{mmol})$ and palladium on carbon $(10 \% \mathrm{Pd}, 0.10 \mathrm{~g})$ in EtOH/EtOAc $(1: 1,20 \mathrm{~mL})$ was stirred under $\mathrm{H}_{2}$ (balloon pressure) at $25{ }^{\circ} \mathrm{C}$ for $6 \mathrm{~h}$. Subsequently, the mixture was filtered through a short pad of Celite and the filtrate was then concentrated under reduced pressure. The residue was purified by column chromatography using hexane/EtOAc (3:1) as the eluent to afford the alcohol 7 (0.80 g, 71\% yield) as a white solid. M.p.: 106.0-108.2 ${ }^{\circ} \mathrm{C} ;{ }^{1} \mathrm{H}$ NMR: 1.52 (s, 9 H), 4.20-4.55 (br, 4 H), 5.97 (brs, 1 H), 6.96-7.05 (m, 4 H), 7.14-7.25 (br, 4 H), 7.60 (d, $J=8.6 \mathrm{~Hz}, 1 \mathrm{H}), 7.66(\mathrm{~d}, J=8.6 \mathrm{~Hz}, 1 \mathrm{H}) ;{ }^{13} \mathrm{C} \mathrm{NMR}: 28.3,48.6,49.3,85.1,109.3,115.3$, $118.2,125.9,126.5,128.3,129.0,129.3,129.5,133.9,153.9,155.8,161.0,162.9$; MS(HR-ESI): calcd for $\mathrm{C}_{23} \mathrm{H}_{24} \mathrm{FNO}_{3} \mathrm{Na} m / z=404.1632$; found $\mathrm{m} / \mathrm{z}=404.1642$ $\left[(\mathrm{M}+\mathrm{Na})^{+}, 100 \%\right]$

\section{Procedure for the Construction of Dialkylammonium Tethered MCM-41. MCM-41}

was prepared according to literature procedures. ${ }^{2}$ Surfactants were removed by calcinations at $550{ }^{\circ} \mathrm{C}$ for $5 \mathrm{~h}$. Surfactant removal is confirmed based on the shifts in the 
Bragg peaks and also by the $\mathrm{N}_{2}$ isotherms. MCM-41 was derivatized with isocyanatopropyltriethoxysilane (ICPES) using a gas-phase reaction between MCM-41 and an ICPES-PhMe solution. The reaction was run for $12 \mathrm{~h}$ under $\mathrm{N}_{2}(1 \mathrm{~atm})$. The ICPES-derivatized material was soaked in PhMe for $1 \mathrm{~d}$ to remove adsorbed ICPES, followed by filtering and drying under reduced pressure. Refluxing ICPES-modified MCM-41 in a $\mathrm{CH}_{2} \mathrm{Cl}_{2}$ solution of the naphthol 7 for $1 \mathrm{~d}$ under $\mathrm{N}_{2}$ (1 atm) afforded dialkylammonium tethered MCM-41. The addition of 3 equiv of trifluoroacetic acid (TFA) to the material in $\mathrm{CH}_{2} \mathrm{Cl}_{2}$ solution for $2 \mathrm{~h}$, yielded the corresponding dialkylammonium salt with $\mathrm{CF}_{3} \mathrm{CO}_{2}^{-}$as the counterion. The loading of guest molecules was done by soaking the derivatized material in a solution of coumarin 460 with a concentration of $0.4 \mathrm{mM}$. The loaded material was capped with 1 equiv of DB24C8 in $\mathrm{CH}_{2} \mathrm{Cl}_{2}$ solution. The material was washed extensively to remove adsorbed coumarin 460.

Discussion of Results. The operation of the valve and the controlled release were studied using luminescene spectroscopy. The material was placed at the bottom of a cell such that only the solution $\left(\mathrm{CH}_{2} \mathrm{Cl}_{2}\right)$ was exposed to the excitation life $(351 \mathrm{~nm}, 5 \mathrm{~mW})$. The solution was stirred at a low stirring rate (1.5 setting in Corning Stirrer/Hot plate) to create a homogenous solution at any given time. The release of coumarin 460 into solution was monitored by luminescence spectroscopy of coumarin 460 in solution over time. This task was achieved by using a charge-coupled device (CCD) detector. This CCD detector provided an in situ measurement of luminescence intensity-either by scanning at a specific wavelength or a range of wavelengths - giving a three-dimensional 
plot of luminescence intensity, wavelength and time, while at the same time confirming the identity of the molecules being released. By considering only the maximum luminescence intensities of the three-dimensional plot, we obtained a two dimensional plot of the luminescence intensity versus time. By correlating the change in luminescence intensity to percentage of release, we obtained a plot of percentage release versus time. Figure S1 shows that coumarin 460 is the species being released over time upon the addition of bases (20-30 $\mu \mathrm{L}, 1$ equiv of the corresponding base based on 1 equiv of the dialkylammonium thread).

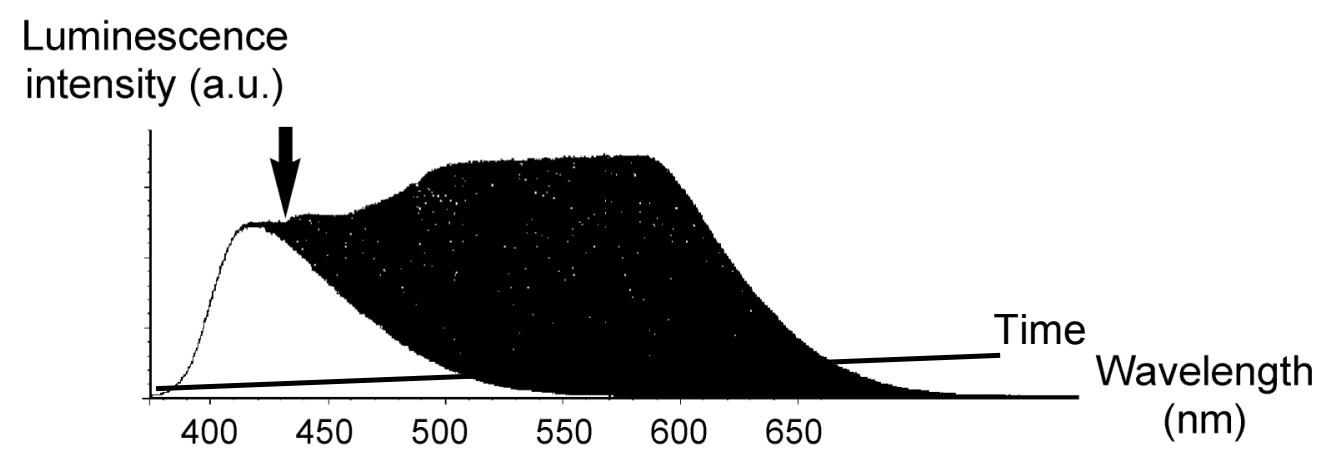

Figure S1. Three-dimensional luminescence spectra recorded over time for the release of coumarin 460 from the naphthalene-containing dialkylammonium-DB24C8 valve.

A control experiment was carried out to verify whether the nanovalve's operation was induced by a base activation via deprotonation or via a competitive binding mechanism of crown ether in the presence of a secondary salt. The binding experiment between DB24C8 and a chosen base was performed and characterized by ${ }^{1} \mathrm{H}$ NMR spectroscopy. Specifically, mixing DB24C8 and excess amount (30 equiv) of $\mathrm{Et}_{3} \mathrm{~N}$ in $\mathrm{CHCl}_{3}$ at $25{ }^{\circ} \mathrm{C}$ (Figure S2), resulted in no shifting of proton resonance signals of the DB24C8. These observations indicate that there is no interaction between the DB24C8 and $\mathrm{Et}_{3} \mathrm{~N}$. 
Subsequently, excess TFA was added to the previously described mixture to consume all the free bases, by forming the corresponding salt $\mathrm{Et}_{3} \mathrm{NH}^{+} \cdot \mathrm{CF}_{3} \mathrm{CO}_{2}^{-}$. However, the salt formed has no interaction with the DB24C8 in the solution, judging from the same resonance signals compared to the original spectrum of DB24C8. As a consequence, $\mathrm{Et}_{3} \mathrm{~N}$ is the base to deprotonate the dialkylammonium ion center to unlock the crown ether from the valve, instead of extracting the crown ether by a competitive binding mechanism.

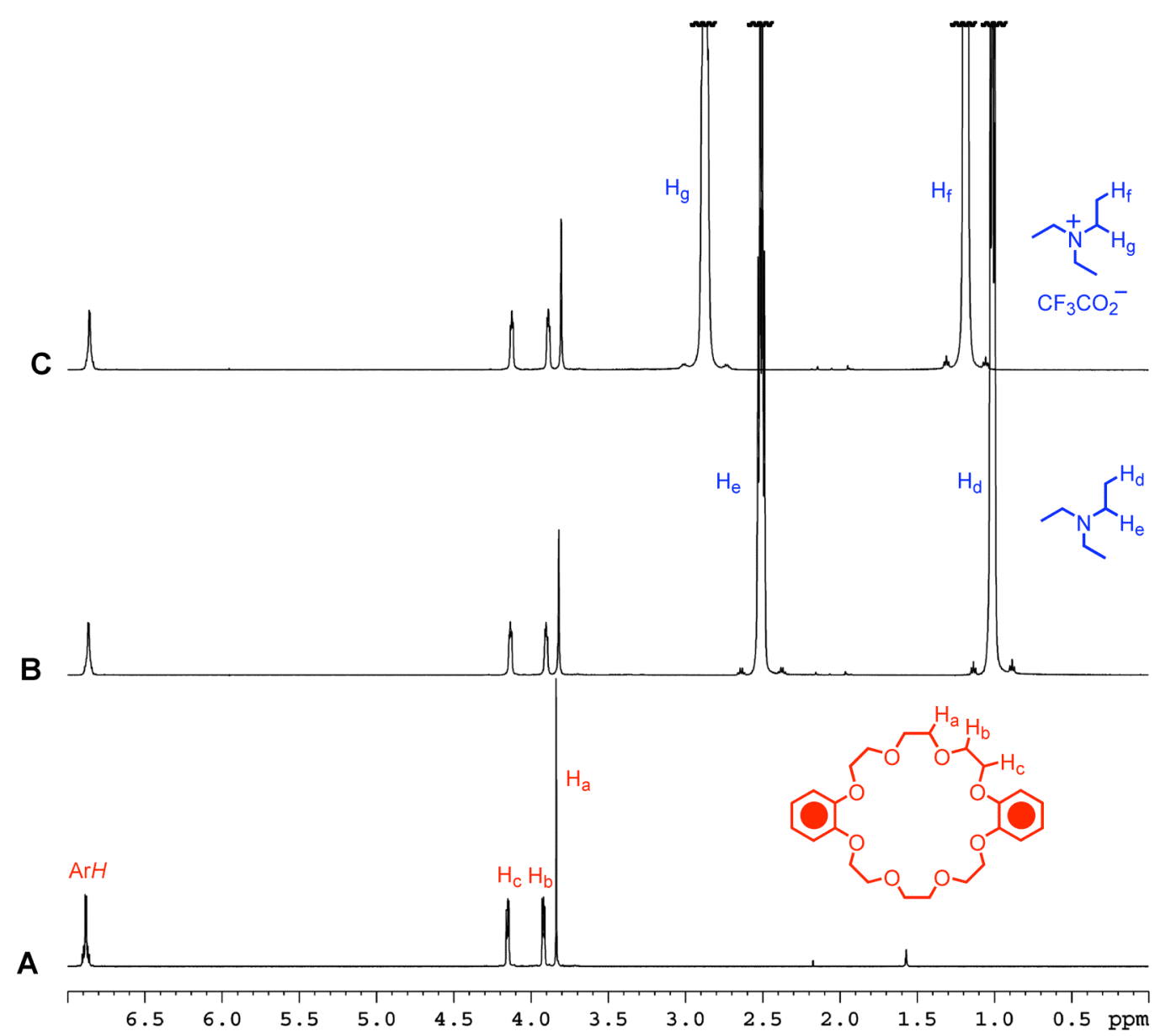

Figure S2. Stacked ${ }^{1} \mathrm{H}$ NMR spectra $\left(\mathrm{CDCl}_{3}, 298 \mathrm{~K}, 500 \mathrm{MHz}\right)$ of the DB24C8 binding experiments. (A) DB24C8, (B) solution A after the addition of excess of $\mathrm{Et}_{3} \mathrm{~N}$ and (C) solution B after the addition of excess of TFA. These results indicate that DB24C8 has no interaction with $\mathrm{Et}_{3} \mathrm{~N}$ and the salt $\mathrm{Et}_{3} \mathrm{NH}^{+} \cdot \mathrm{CF}_{3} \mathrm{CO}_{2}^{-}$. 
Figure $\mathrm{S} 3$ shows the XRD pattern of the MCM-41 material after calcination. The pattern shows a broad peak at $2 \theta=3.1$ [indexed as (100)] and a shoulder at 5.0. The highly ordered material is expressed to be a 2-dimensional hexagonal structure that has a lattice spacing of $3.6 \mathrm{~nm}$.

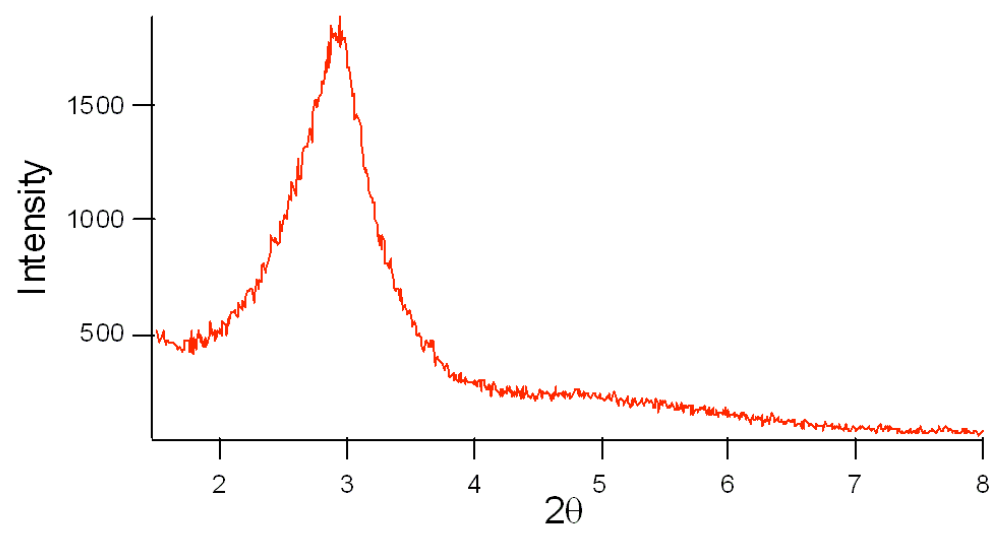

Figure S3. XRD pattern of the MCM-41 after calcination.

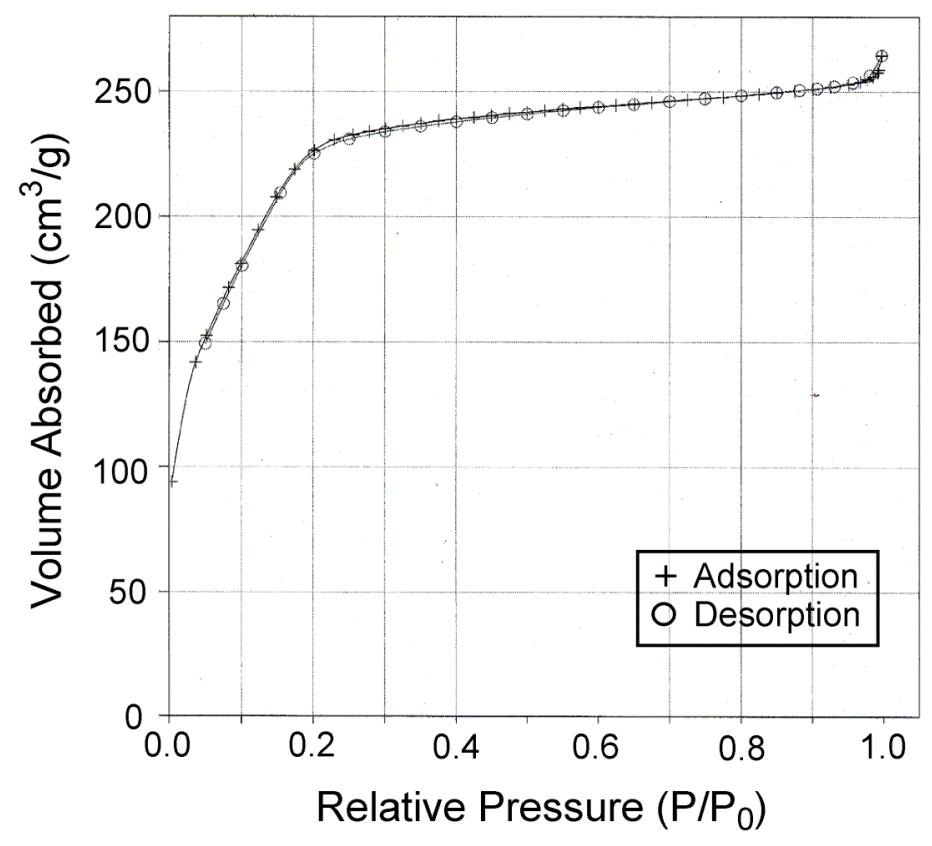

Figure S4. Nitrogen adsorption/desorption isotherm of the MCM-41 materials after calcination. 
Figure S4 shows the $\mathrm{N}_{2}$ sorption of the material at $77 \mathrm{~K}$. This isotherm can be classified as type IV isotherm according to IUPAC nomenclature. Calculation by the BrunauerEmmett-Teller (BET) method indicates a highly porous material with pore volume of $0.77 \mathrm{~cm}^{3} / \mathrm{g}$ and a pore diameter of $2.0 \mathrm{~nm}$.

\section{References}

S1. Jullien, L.; Canceill, J.; Valeur, B.; Bardez, E.; Lefevre, J.-P.; Lehn, J.-M.; Marchi-Artzner, V.; Pansu, R. J. Am. Chem. Soc. 1996, 118, 5432-5442.

S2. Grun, M; Laner, I.; Unger, K. K. Adv. Mater. 1997, 9, 254-257. 